\title{
ANALISIS PENGARUH KETERAMPILAN MENGAJAR, EMOSI MAHASISWA, TEKANAN AKADEMIK DAN PERCEIVED ACADEMIC CONTROL TERHADAP PRESTASI AKADEMIK MAHASISWA MENGGUNAKAN PENDEKATAN SEM-PLS
}

\author{
Adnan Sauddin ${ }^{\mathrm{i}}$, Nur Suci Ramadhani ${ }^{\mathrm{ii}}$
}

i Prodi Matematika FST, UINAM, Adnan.sauddin@uin-alauddin.ac.id
ii Mahasiswa Program Studi Matematika-FST, UINAM

ABSTRAK, Pendidikan merupakan salah satu faktor yang berperan penting dalam kehidupan masyarakat. Pendidikan yang berkualitas dapat dilihat dari prestasi yang dicapai, sehingga mengetahui faktor-faktor prestasi belajar merupakan hal yang penting dalam pencapaian prestasi maksimal. Dalam penelitian ini diasumsikan variabel keterampilan mengajar, emosi mahasiswa, tekanan akademik dan perceived academic control berpengaruh terhadap prestasi akademik. Dengan pendekatan statistik Structural Equation Modeling Partial Least Square (SEMPLS) diperoleh hasil penelitian bahwa variabel keterampilan mengajar, emosi mahasiswa, tekanan akademik dan perceived academic control tidak berpengaruh terhadap prestasi akademik. Namun, keterampilan mengajar berpengaruh terhadap emosi mahasiswa, tekanan akademik dan perceived academic control. Tekanan akademik juga berpengaruh terhadap emosi mahasiswa.

Kata Kunci: SEM-PLS, Keterampilan Mengajar, Emosi Mahasiswa, Tekanan Akademik, Perceived Academic Control, Prestasi Akademik

\section{PENDAHULUAN}

Pendidikan yang berkualitas dapat dilihat dari prestasi yang dicapai, sehingga untuk memperoleh prestasi yang maksimal maka perlu diketahui faktor-faktor yang mempengaruhi prestasi belajar. Faktor-faktor yang mempengaruhi prestasi belajar terdiri faktor eksternal dan faktor internal.

Berdasarkan penelitian Vella Anggresta (2006) faktor eksternal yang dominan mempengaruhi prestasi belajar adalah keterampilan mengajar [1]. Keterampilan dosen dalam mengajar dapat membangkitkan motivasi mahasiswa untuk belajar yang akan meningkatkan hasil belajarnya. Berdasarkan hasil survey Irma Harun, M. Daud dan Asniar Khumas pada 102 mahasiswa di perguruan tinggi di Makassar, diperoleh hasil bahwa mahasiswa yang mengalami tingkat stres yang rendah sebanyak 18\%, mahasiswa yang mengalami tingkat stres yang sedang sebanyak
$67 \%$, dan 15\% mahasiswa mengalami tingkat stres yang tinggi. Stres yang dirasakan oleh mahasiswa tersebut berhubungan dengan tugas kuliah yang harus dikerjakan dalam waktu yang bersamaan, keadaan kelas yang tidak nyaman, tuntutan untuk berprestasi dari keluarga.[2]

Lingkungan pendidikan yang kondusif, keterampilan dosen yang baik dan terstruktur dalam mengajar, akan berdampak kepada pemahaman mahasiswa dimana mahasiswa akan memahami materi pengajaran yang disampaikan atau sekurang-kurangnya mahasiswa akan konsentrasi mengikuti perkuliahan dan berusaha memahami apa yang diajarkan yang akan berdampak pada tercapainya tujuan belajar.

Selain faktor eksternal, menurut pengalaman dan pengamatan peneliti faktor internal yang dominan mempengaruhi prestasi belajar adalah emosi mahasiswa dan perceived academik control. Para ahli psikologi menyebutkan bahwa keberhasilan hidup salah satunya prestasi belajar hanya dipengaruhi sebesar $20 \%$ oleh fakor IQ dan sisanya $80 \%$ dipengaruhi oleh faktor lain, salah satu yang dominan adalah kecerdasan emosi.[3]

Dalam proses belajar mengajar, manusia memiliki potensi untuk merasakan emosi positif dan emosi negatif. Emosi tersebut menjadi kekuatan bagi mahasiswa. Berdasarkan pengalaman peneliti emosi positif yang dirasakan dapat memberi manfaat, membangkitkan semangat dan meningkatkan ketekunan serta mengaktifkan aspirasi dan motivasi selama proses perkuliahan yang akan berdampak pada perceived academic control mahasiswa dan prestasi belajar yang dicapai. Sebaliknya emosi negatif yang dirasakan dapat mendorong mahasiswa untuk kurang semangat dan kurang percaya diri dalam belajar serta tidak fokus terhadap materi perkuliahan. Emosi berlaku 
sebagai pengarah manusia yang paling kuat yang akan mempengaruhi kontrol yang dirasakan oleh mahasiswa.

Mahasiswa yang memiliki tingkat kontrol akademik yang rendah akan mengalami lebih banyak kebosanan dan kecemasan saat belajar, kurang termotivasi, kurang berusaha daripada mahasiswa dengan tingkat kontrol yang tinggi. Mahasiswa dengan kontrol akademik yang tinggi akan belajar dan berusaha lebih keras dan memiliki karir akademis yang lebih produktif.[4] Terkait dengan faktor-faktor yang mempengaruhi prestasi akademik mahasiswa dalam penelitian ini menggunakan metode statistik Structural Equation Modeling (SEM) pendekatan Partial Least Square (PLS). Penggunaan pendekatan Partial Least Square memungkinkan hubungan antar variabel sangat kompleks dengan banyak variabel dependen dan variabel independen, memungkinkan peneliti untuk memprediksi model yang memiliki landasan teori yang lemah, dapat digunakan pada data yang tidak berdistribusi normal dan menggunakan ukuran sampel yang kecil. Selain itu, dalam PLS juga mengizinkan peneliti untuk menggunakan indikator bersifat reflektif maupun formatif.

\section{TINJAUAN PUSTAKA}

\section{STRUCTURAL EQUATION MODELING (SEM)}

Structural Equation Modeling (SEM) SEM memiliki kemampuan dalam menyelesaikan permasalahan dengan model dan hubungan antarvariabel yang sangat kompleks. SEM dapat digunakan pada model penelitian yang terdiri atas banyak variabel terikat dan banyak variabel bebas.

Variabel Laten merupakan variabel yang tidak dapat diamati atau diukur secara langsung tetapi dapat dipresentasikan oleh variabel-variabel manifest yang terdiri dari variabel laten eksogen $(\xi)$ dan variabel laten endogen $(\eta)$.[5]

\section{PARTIAL LEAST SQUARE (PLS)}

PLS merupakan metode alternatif SEM yang asumsi-asumsinya tidak seketat yang ada pada SEM berbasis kovarian. SEM-PLS memberi kelonggaran dalam penggunaan ukuran sampel yang tidak harus besar, data yang tidak berdistribusi normal multivariat dan memperbolehkan indikator formatif dalam mengukur variabel laten selain indikator reflektif. Selain itu, PLS juga memberi kelonggaran pada peneliti untuk menggunakan skala pengukuran selain interval.

Model Struktural yaitu model yang menggambarkan hubungan antarvariabel laten. Secara matematis dapat dituliskan sebagai berikut:

$$
\boldsymbol{\eta}_{(m \times 1)}=\mathbf{B}_{(m \times m)} \boldsymbol{\eta}_{(m \times 1)}+\boldsymbol{\Gamma}_{(m \times n)} \boldsymbol{\xi}_{(n \times 1)}+\boldsymbol{\zeta}_{(m \times 1)} .
$$

$\boldsymbol{\eta}=$ vektor variabel laten endogen

$\boldsymbol{\xi}=$ vektor variabel laten eksogen

$\mathbf{B}=$ matriks koefisien variabel laten endogen

$\boldsymbol{\Gamma}=$ matriks koefisien yang menghubungkan variabel laten endogen dengan eksogen

Model Pengukuran yaitu model yang menggambarkan hubungan antara variabel laten dengan variabel manifestnya yang secara matematis dapat dituliskan sebagai berikut:

$$
\begin{aligned}
& \mathbf{y}_{(p \times 1)}=\boldsymbol{\Lambda}_{\mathbf{y}(p \times m)} \boldsymbol{\eta}_{(m \times 1)}+\boldsymbol{\varepsilon}_{(p \times 1)} . \\
& \mathbf{x}_{(q \times 1)}=\Lambda_{\mathbf{x}(q \times n)} \boldsymbol{\xi}_{(n \times 1)}+\boldsymbol{\delta}_{(q \times 1)} .
\end{aligned}
$$

$\mathbf{y}=$ vektor dari variabel manifes endogen

$\mathbf{x}=$ vektor dari variabel manifes eksogen

$\boldsymbol{\Lambda}_{\mathbf{y}}=$ matriks koefisien antara variabel endogen dengan indikator-indikatornya

$\boldsymbol{\Lambda}_{\mathrm{x}}=$ matriks koefisien antara variabel eksogen dengan indikator-indikatornya

$\boldsymbol{\varepsilon}=$ vektor dari kesalahan pengukuran

$\boldsymbol{\delta}=$ vektor dari kesalahan pengukuran

$\mathrm{p}$ = banyaknya indikator variabel endogen

$\mathrm{q}$ = banyaknya indikator variabel eksogen

\section{PENGUKURAN KEBAIKAN MODEL SEM-} PLS

Pengujian kebaikan model pengukuran digunakan untuk menguji validitas dan reliabilitas instrument. Validitas yang diuji dalam SEM-PLS terdiri atas validitas konvergen dan validitas diskriminan. Berikut diuraikan pengujian kebaikan model pengukuran dalam SEM-PLS sebagai berikut:

1) Validitas konvergen, menggambarkan bahwa seperangkat indikator mewakili satu variabel laten dan mendasari variabel laten tersebut. Hal ini menjelaskan bahwa indikatorindikator dari suatu variabel laten harus 
memiliki korelasi yang tinggi. Untuk menguji validitas konvergen dalam model pengukuran parameter yang harus diperhatikan adalah sebagai berikut:

a) Faktor loading. Jika nilai faktor loading > 0.7 maka dianggap indikator yang mengukur variabel laten tersebut signifikan.

b) Average Variance Explained (AVE). nilai AVE dapat diperoleh menggunakan persamaan sebagai berikut :

$$
A V E=\frac{\sum \lambda_{i}^{2}}{\sum \lambda_{i}^{2}+\sum \operatorname{var}\left(\varepsilon_{i}\right)} .
$$

Validitas konvergen terpenuhi jika nilai AVE $>0.5$.

2) Validitas diskriminan, menggambarkan kemampuan setiap variabel laten dalam mendiskriminasikan dirinya dengan variabel laten lainnya. Hal ini menjelaskan bahwa indikator-indikator dari suatu variabel laten harus berkorelasi tinggi dengan variabel laten yang mendasarinya dan berkorelasi lemah dengan variabel laten yang lain. Untuk menguji validitas diskriminan dalam model pengukuran parameter yang harus diperhatikan adalah nilai cross loading. Nilai cross loading harus $>0.7$ dalam satu variabel atau nilai cross loading indikator yang mengukur variabel latennya harus lebih tinggi dibandingkan dengan variabel laten lainnya.

3) Uji reliabilitas. Uji reliabilitas dilakukan untuk mengukur konsistensi, keakuratan dan ketepatan suatu indikator dalam melakukan pengukuran. Pengujian reliabilitas dalam SEM-PLS dilakukan dengan melihat parameter Composite reliability (CR) yang dapat diperoleh menggunakan persamaan sebagai berikut:

$$
C R=\frac{\left(\sum \lambda_{i}\right)^{2}}{\left(\sum \lambda_{i}\right)^{2}+\sum \operatorname{var}\left(\varepsilon_{i}\right)}
$$

Nilai CR harus $\geq 0,7$

Selanjutnya pengukuran kebaikan model struktural menggunakan parameter Q-square predictive relevant dihitung dengan persamaan sebagai berikut:

$$
Q^{2}=1-\left(1-R_{1}^{2}\right)\left(1-R_{2}^{2}\right) \ldots\left(1-R_{p}^{2}\right),
$$

dimana $R_{1}^{2}, \ldots, R_{p}^{2}$ adalah $R$-squared variabel endogen. Interpretasinya mirip dengan koefisien determinasi $\left(R^{2}\right)$ pada analisis regresi.

Sedangkan untuk mengukur kebaikan model struktural dan pengukuran secara keseluruhan nilai yang diperhatikan adalah nilai Goodness of Fit (GoF) Index yang diperoleh dengan rumus sebagai berkut:

$$
\text { GoF }=\sqrt{\overline{\text { communality }} \times \overline{R^{2}}} .
$$

Interpretasinya yaitu GoF $\geq 0.1$ (GoF small), $\geq$ 0.25 (GoF moderat), dan $\geq 0.36$ (GoF large).[7]

\section{UJI SIGNIFIKAN PARAMETER SEM-PLS}

Berikut pengujian hipotesis statistik untuk setiap model:

1. Rumusan hipotesis statistik untuk model pengukuran:

$$
\begin{aligned}
& \mathrm{H}_{0}: \lambda_{\mathrm{i}}=0 \\
& \mathrm{H}_{1}: \lambda_{\mathrm{i}} \neq 0
\end{aligned}
$$

Statistik uji yang digunakan untuk menguji hipotesis tersebut adalah $t$-tsudent dengan bentuk matematikanya sebagai berikut :

$$
t=\frac{\hat{\lambda}}{S E(\hat{\lambda})} .
$$

2. Rumusan hipotesis statistik untuk model struktural yang menghubungkan antara variabel laten eksogen dan variabel laten endogen adalah sebagai berikut:

$$
\begin{aligned}
& H_{0}: \gamma_{i}=0 \\
& H_{1}: \gamma_{i} \neq 0
\end{aligned}
$$

Statistik uji yang digunakan untuk menguji hipotesis tersebut adalah $t$-tsudent dengan bentuk sebagai berikut :

$$
t=\frac{\hat{\gamma}}{S E(\hat{\gamma})},
$$

3. Rumusan hipotesis statistik untuk model struktural yang menghubungkan antar variabel laten endogen adalah sebagai berikut:

$$
\begin{aligned}
& H_{0}: \beta_{i}=0 \\
& H_{1}: \beta_{i} \neq 0
\end{aligned}
$$

Statistik uji yang digunakan menguji hipotesis tersebut adalah t-tsudent dengan bentuk matematikanya sebagai berikut : 


$$
t=\frac{\hat{\beta}}{S E(\hat{\beta})} .
$$

Jika diperoleh nilai t-hitung $>-1.96$ dan $<1.96$ pada taraf signifikan $5 \%$ atau dengan $p$-value $\leq$ 0,05 (alpha $5 \%$ ) maka dapat disimpulkan bahwa parameter signifikan.

\section{PRESTASI AKADEMIK}

Prestasi akademik merupakan hasil pencapaian yang diperoleh dari kegiatan belajar dalam jangka waktu tertentu yang dapat diukur atau dinilai dari evaluasi pengajar. Prestasi akademik yang tinggi menggambarkan kemampuan mahasiswa yang tinggi, demikian sebaliknya. Oleh karena itu, secara tidak langsung prestasi yang dicapai menjadi salah satu penentu dalam keberhasilan mahasiswa dan cerminan mahasiswa yang berkualitas.

Indikator yang digunakan dalam mengukur prestasi akademik adalah Indeks Prestasi Komulatif (IPK).[8] Salah satu faktor yang berpengaruh terhadap prestasi belajar yang diperoleh mahasiswa adalah keterampilan mengajar, tekanan akademik serta emosi mahasiswa dan perceived academik control.

\section{METODOLOGI}

\section{Sumber Data}

Data yang digunakan adalah data primer dan data sekunder. Data primer diperoleh dari responden untuk memperoleh data mengenai keterampilan mengajar dosen, emosi mahasiswa, tekanan akademik dan perceived academic control mahasiswa dan data sekunder diperoleh dari jurusan Matematika Fakultas Sains dan Teknologi UIN Alauddin Makassar untuk memperoleh data tentang Indeks Prestasi Komulatif (IPK) mahasiswa.

\section{Variabel Penelitian}

Variabel penelitian yang digunakan terdiri dari satu variabel laten eksogen dan empat variabel laten endogen yang terdiri dari beberapa indikator yang dapat dilihat dalam tabel di bawah ini:

\begin{tabular}{|l|c|l|}
\hline \multicolumn{1}{|c|}{ Variabel Laten Eksogen } & & Indikator (Variabel Manifest) \\
\hline Keterampilan Mengajar & $\mathrm{X}_{11}$ & Penguasaan Materi \\
\hline & $\mathrm{X}_{21}$ & Metode/Pendekatan Mengajar \\
\hline & $\mathrm{X}_{31}$ & Pengeloaan Kelas \\
\hline & $\mathrm{X}_{41}$ & Perencanaan Mengajar \\
\hline Variabel Laten Endogen & & \\
\hline Emosi Mahasiswa & $\mathrm{Y}_{11}$ & Kesenangan \\
\hline & $\mathrm{Y}_{21}$ & Harapan \\
\hline & $\mathrm{Y}_{31}$ & Kekecewaan \\
\hline & $\mathrm{Y}_{41}$ & Putus Asa \\
\hline Tekanan Akademik & $\mathrm{Y}_{12}$ & Tekanan Prestasi \\
\hline & $\mathrm{Y}_{22}$ & Tekanan Tugas \\
\hline & $\mathrm{Y}_{32}$ & Tekanan Ujian \\
\hline & $\mathrm{Y}_{42}$ & Tekanan Pembelajaran \\
\hline Perceived Academic Control & $\mathrm{Y}_{13}$ & Control Belief \\
\hline & $\mathrm{Y}_{23}$ & Perceived Power \\
\hline Prestasi Akademik & $\mathrm{Y}_{14}$ & IPK \\
\hline Prosedur Amalisis & & \\
\hline
\end{tabular}

\section{Prosedur Analisis}

Adapun langkah-langkah analisis dalam penelitian ini adalah sebagai berikut:

a. Merancang model struktural (inner model

b. Merancang model pengukuran (outer model)

c. Mengkonstruksi diagram jalur berdasarkan model.

d. Mengkonversi diagram jalur ke sistem persamaan.

e. Melakukan estimasi parameter

f. Mengukur kebaikan model

g. Melakukan pengujian hipotesis

h. Interpretasi hasil analisis

\section{PEMBAHASAN}

\section{RINGKASAN STATISTIK}

Nilai statistik untuk masing-masing indikator pada setiap variabel ditampilkan sebagai berikut:

Tabel 4.1 Ringkasan Statistik

\begin{tabular}{ccccc}
\hline Variabel & Indikator & Mean & Z-skew & Z-kurt \\
\hline Keterampilan Mengajar & $\mathrm{X}_{11}$ & 3.753 & -0.366 & -0.089 \\
& $\mathrm{X}_{21}$ & 3.753 & -0.508 & -0.044 \\
& $\mathrm{X}_{31}$ & 2.516 & 0.583 & -1.094 \\
& $\mathrm{X}_{41}$ & 3.516 & -0.260 & 0.032 \\
\hline Emosi Mahasiswa & $\mathrm{Y}_{11}$ & 3.753 & -1.263 & 0.064 \\
& $\mathrm{Y}_{21}$ & 3.368 & -0.832 & 0.054 \\
& $\mathrm{Y}_{31}$ & 3.516 & -0.890 & 0.029 \\
& $\mathrm{Y}_{41}$ & 3.753 & -0.516 & -0.310 \\
\hline Tekanan Akademik & $\mathrm{Y}_{12}$ & 3.753 & -0.963 & 0.125 \\
& $\mathrm{Y}_{22}$ & 3.753 & -0.782 & -0.067 \\
& $\mathrm{Y}_{32}$ & 3.753 & -0.933 & -0.160 \\
& $\mathrm{Y}_{42}$ & 3.368 & -0.583 & -0.105 \\
\hline Perceived Academic Control & $\mathrm{Y}_{13}$ & 3.753 & -0.759 & -0.259 \\
& $\mathrm{Y}_{23}$ & 3.368 & -0.346 & -0.057 \\
\hline Prestasi Akademik & $\mathrm{Y}_{14}$ & 3.368 & -6.738 & 12.657 \\
\hline
\end{tabular}

Dari data tersebut nampak bahwa nilai z-skew dan z-kurt dari setiap indikator $>-1.96$ dan $<1.96$ kecuali indikator $\mathrm{Y}_{14}$ (IPK). Dari keadaan 
tersebut menggambarkan keadaan data cenderung berdistribusi normal kecuali indikator $\mathrm{Y}_{14}(\mathrm{IPK})$.

\section{MENGUKUR KEBAIKAN MODEL}

a. Mengukur Kebaikan Model Pengukuran Penilaian terhadap model pengukuran dilakukan dengan memperhatikan kemampuan setiap indikator dalam mengukur variabel latennya dengan menguji validitas dan reliabilitas setiap indikator terhadap variabel latennya melalui pengujian validitas konvergen, validitas diskriminan dan composite reliability.

Pengujian validitas konvergen ditentukan dengan memperhatikan parameter faktor loading dan AVE. Nilai faktor loading setiap indikator dapat dilihat dalam gambar berikut ini:

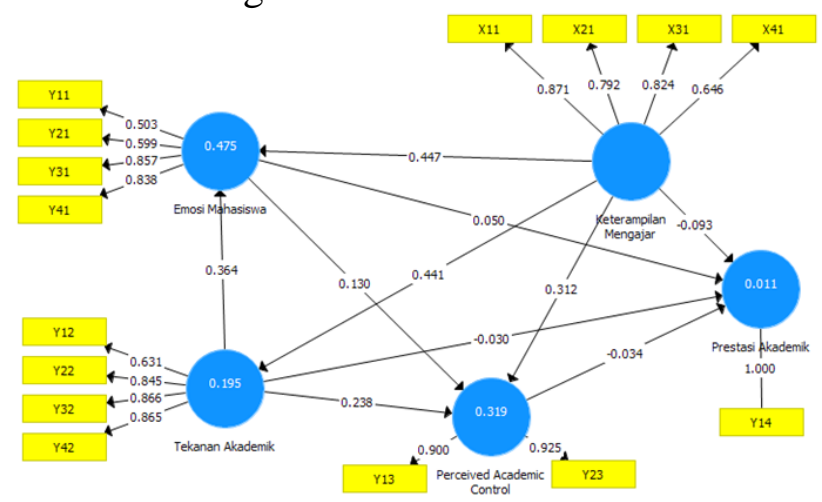

Gambar 4.1 Faktor Loading

Perhatikan gambar 4.1. Terdapat empat indikator yang memiliki faktor loading kurang dari 0.7 yaitu indikator $\mathrm{X}_{41}, \mathrm{Y}_{11}, \mathrm{Y}_{21}$ dan $\mathrm{Y}_{12}$. Hal ini menunjukkan keempat indikator tersebut memiliki korelasi yang lemah terhadap konstruknya. Sehingga perlu dilakukan perubahan model yang tidak lagi mengikutkan keempat indikator yang terindikasi memiliki korelasi yang lemah. Perubahan model ditunjukkan dalam gambar 4.2 sebagai berikut:

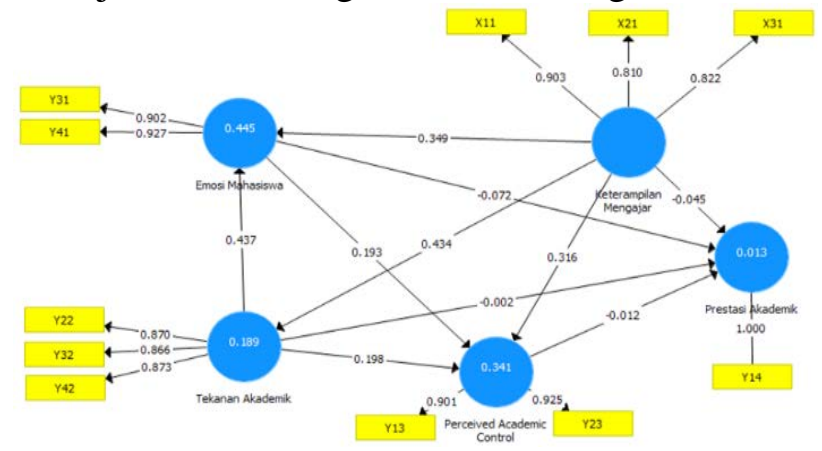

Gambar 4.2 Faktor Loading Setelah Perubahan Model
Dari gambar 4.2 menunjukkan bahwa setelah dilakukan perubahan model nampak bahwa korelasi setiap indikator dengan variabel latennya sudah kuat. Selanjutnya dilakukan pengujian validitas konvergen dilihat dari parameter AVE sebagai berikut:

Tabel 4.2 Nilai AVE

\begin{tabular}{lc}
\hline \multicolumn{1}{c}{ Variabel } & AVE \\
\hline Keterampilan Mengajar & 0.716 \\
Emosi Mahasiswa & 0.836 \\
Tekanan Akademik & 0.756 \\
Perceived Academic Control & 0.834 \\
Prestasi Akademik & 1.000 \\
\hline
\end{tabular}

Berdasarkan tabel 4.2, nampak bahwa nilai AVE setiap variabel $>0.5$ sehingga disimpulkan validitas konvergen dalam penelitian ini valid. Hal ini menggambarkan bahwa kemampuan setiap indikator dalam menjelaskan variabel latennya adalah valid.

Pengujian validitas diskriminan dapat ditentukan dengan memperhatikan parameter cross loading yang dapat dilihat dalam tabel berikut ini:

Tabel 4.3 Nilai Cross Loading

\begin{tabular}{l|c|cccc}
\hline \multicolumn{2}{c}{$\begin{array}{c}\text { Keterampilan } \\
\text { Mengajar }\end{array}$} & $\begin{array}{c}\text { Emosi } \\
\text { Mahasiswa }\end{array}$ & $\begin{array}{c}\text { Tekanan } \\
\text { Akademik }\end{array}$ & $\begin{array}{c}\text { Perceived } \\
\text { Academic Control }\end{array}$ & $\begin{array}{c}\text { Prestasi } \\
\text { Akademik }\end{array}$ \\
\hline $\mathrm{X}_{11}$ & 0.903 & 0.467 & 0.440 & 0.516 & -0.113 \\
$\mathrm{X}_{21}$ & 0.810 & 0.408 & 0.263 & 0.389 & 0.037 \\
$\mathrm{X}_{31}$ & 0.822 & 0.490 & 0.378 & 0.365 & -0.132 \\
$\mathrm{Y}_{31}$ & 0.448 & 0.902 & 0.531 & 0.401 & -0.020 \\
$\mathrm{Y}_{41}$ & 0.533 & 0.927 & 0.546 & 0.472 & -0.160 \\
$\mathrm{Y}_{22}$ & 0.415 & 0.514 & 0.870 & 0.431 & 0.006 \\
$\mathrm{Y}_{32}$ & 0.368 & 0.526 & 0.866 & 0.334 & -0.072 \\
$\mathrm{Y}_{42}$ & 0.348 & 0.497 & 0.873 & 0.402 & -0.120 \\
$\mathrm{Y}_{13}$ & 0.411 & 0.438 & 0.377 & 0.901 & -0.079 \\
$\mathrm{Y}_{23}$ & 0.507 & 0.438 & 0.439 & 0.925 & -0.051 \\
$\mathrm{Y}_{14}$ & -0.091 & -0.103 & -0.070 & 0.070 & 1.000
\end{tabular}

Berdasarkan tabel di atas, nampak bahwa nilai cross loading atau nilai korelasi setiap indikator terhadap variabel latennya memiliki nilai korelasi yang tinggi jika dibandingkan dengan varibel laten lainnya. Hal ini menggambarkan bahwa setiap variabel laten mampu mendiskriminasikan dirinya dengan variabel laten lainnya. Hal tersebut juga bermakna bahwa setiap variabel laten memiliki hubungan yang paling kuat dengan indikatornya dibandingkan dengan variabel laten lainnya sehingga disimpulkan bahwa validitas discriminan setiap variabel adalah valid.

Parameter yang digunakan untuk menilai reliabilitas atau menilai akurasi, konsistensi dan ketepatan indikator dalam melakukan 
pengukuran dapat ditentukan dengan memperhatikan nilai composite reliability sebagaimana yang ditunjukkan dalam tabel 4.3 sebagai berikut:

Tabel 4.4 Nilai Composite Reliability

\begin{tabular}{lc}
\hline \multicolumn{1}{c}{ Variabel Laten } & $\begin{array}{c}\text { Composite } \\
\text { Reliability }\end{array}$ \\
\hline Keterampilan Mengajar & 0.883 \\
Emosi Mahasiswa & 0.911 \\
Tekanan Akademik & 0.903 \\
Perceived Academic Control & 0.909 \\
Prestasi Akademik & 1.000 \\
\hline
\end{tabular}

Berdasarkan tabel di atas, nilai composite reliability setiap variabel laten melebihi 0.7 , sehingga reliabitilas terpenuhi.

\section{b. Mengukur Kebaikan Model Struktural}

Penilaian terhadap kebaikan model struktural didasarkan pada nilai koefisien determinasi $\left(\mathrm{R}^{2}\right)$ sebagaimana yang ditunjukkan dalam tabel 4.4 sebagai berikut:

Tabel 4.5 Nilai Koefisien Determinasi $\left(\mathrm{R}^{2}\right)$

\begin{tabular}{lc}
\hline \multicolumn{1}{c}{ Variabel Laten } & $\mathrm{R}^{2}$ \\
\hline Emosi Mahasiswa & 0.445 \\
Tekanan Akademik & 0.189 \\
Perceived Academic Control & 0.341 \\
Prestasi Akademik & 0.013 \\
\hline
\end{tabular}

Dari nilai koefisien determinasi $\left(\mathrm{R}^{2}\right)$ tersebut diperoleh nilai $Q$-square predictive relevant sebesar 0.707 atau $71 \%$. Hal ini bermakna bahwa konstruk endogen prestasi akademik dapat dijelaskan oleh konstruk endogen emosi mahasiswa, tekanan akademik dan perceived academic control sebesar 71 \% dan sisanya dijelaskan oleh variabel lain yang tidak diikutkan di dalam model.

\section{c. Mengukur Kebaikan Model Secara Keseluruhan}

Penilaian kebaikan model pengukuran dan model strukutural secara keseluruhan ditentukan dengan memperhatikan nilai GoF yang merupakan akar dari rata-rata nilai communality dikali akar rata-rata nilai koefisien determinasi diperoleh nilai sebesar 0.405 (kriteria Gof large apabila $\geq 0.36$ ). Hal tersebut bermakna bahwa model memiliki kemampuan yang tinggi dalam menjelaskan data pengamatan, sehingga secara keseluruhan dapat dikatakan model yang terbentuk adalah valid.

\section{PENGUJIAN HIPOTESIS}

Pengujian ini dilakukan dengan memperhatikan nilai $t$-value yang dapat dilihat dalam tabel 4.5 sebagai berikut:

Tabel 4.6 Nilai $t$-value

\begin{tabular}{lccl}
\hline \multicolumn{1}{c}{ Variabel } & $\begin{array}{c}\text { Original } \\
\text { Sample }\end{array}$ & $\begin{array}{c}T \\
\text { Value }\end{array}$ & Keputusan \\
\hline Keterampilan Mengajar -> Emosi Mahasiswa & 0.349 & 4.36 & Terima $\mathrm{H}_{1}$ \\
Keterampilan Mengajar -> Tekanan Akademik & 0.434 & 6.797 & Terima $\mathrm{H}_{1}$ \\
Keterampilan Mengajar->Perceived Academic Control & 0.316 & 3.179 & Terima $\mathrm{H}_{1}$ \\
Keterampilan Mengajar -> Prestasi Akademik & -0.045 & 0.359 & Tolak $\mathrm{H}_{1}$ \\
Tekanan Akademik -> Emosi Mahasiswa & 0.437 & 5.869 & Terima $\mathrm{H}_{1}$ \\
Emosi Mahasiswa -> Perceived Academic Control & 0.193 & 1.355 & Tolak $\mathrm{H}_{1}$ \\
Tekanan Akademik -> Perceived Academic Control & 0.198 & 1.633 & Tolak $\mathrm{H}_{1}$ \\
Emosi Mahasiswa -> Prestasi Akademik & -0.072 & 0.559 & Tolak $\mathrm{H}_{1}$ \\
Tekanan Akademik -> Prestasi Akademik & -0.002 & 0.024 & Tolak $\mathrm{H}_{1}$ \\
Perceived Academic Control-> Prestasi Akademik & -0.012 & 0.133 & Tolak $\mathrm{H}_{1}$ \\
\hline
\end{tabular}

Berdasarkan tabel di atas, diperoleh hasil bahwa berdasarkan data hubungan antar variabel yang signifikan adalah hubungan antara keterampilan mengajar dan tekanan akademik terhadap emosi mahasiswa, hubungan antara keterampilan mengajar terhadap tekanan akademik dan perceived academic control. Sehingga dari hasil analisis diperoleh hasil bahwa keterampilan mengajar, emosi mahasiswa, tekanan akademik dan perceived academic control tidak memiliki pengaruh yang signifikan baik secara langsung maupun tidak langsung terhadap prestasi akademik.

Hal ini menggambarkan bahwa meskipun seorang dosen memiliki keterampilan mengajar yang cukup baik, menguasai materi perkuliahan dengan baik, memiliki kemampuan dalam mengelola kelas yang akan menurunkan tingkat stress belajar mahasiswa yang juga berdampak terhadap terciptanya perasaan nyaman dan tenang di dalam kelas dan cenderung membuat mahasiswa untuk rajin belajar serta memiliki motivasi tersendiri, hal ini tidak membuat pemahaman mahasiswa tentang materi tersebut cenderung meningkat yang secara tidak langsung akan membuat mahasiswa meraih nilai indeks prestasi yang tinggi.

Selain itu, pada dasarnya mahasiswa sudah mampu memperoleh referensi dan mengkaji materi perkuliahan secara mendalam di luar kelas. Hal ini mengakibatkan bahwa terkadang keterampilan mengajar dosen tidak berpengaruh lagi terhadap prestasi mahasiswa karena setelah pembelajaran di kelas telah selesai, mahasiswa 
mampu mengkaji materi sendiri yang akan meningkatkan pemahamannya dengan materi tersebut. Demikian halnya jika mahasiswa merasa bosan dan kurang termotivasi dalam belajar, keadaan kelas yang tidak nyaman, tugas yang terlalu berat, pembelajaran yang tidak efektif. Pada keadaan tertentu, hal tersebut tidak menurunkan keyakinan mahasiswa untuk menujukkan kapasitasnya dalam memperoleh prestasi.

\section{KESIMPULAN}

Adapun kesimpulan dari penelitian ini adalah sebagai berikut :

1. Keterampilan mengajar dan tekanan akademik mempunyai pengaruh yang signifikan secara langsung maupun tidak langsung terhadap emosi mahasiswa

2. Keterampilan mengajar mempunyai pengaruh yang signifikan secara langsung terhadap tekanan akademik

3. Keterampilan mengajar mempunyai pengaruh secara langsung maupun tidak langsung yang signifikan terhadap perceived academic control. Namun, emosi mahasiswa dan tekanan akademik tidak memiliki pengaruh terhadap perceived academic control

4. Keterampilan mengajar, emosi mahasiswa, tekanan akademik dan perceived academic control tidak memiliki pengaruh yang signifikan baik secara langsung maupun tidak langsung terhadap prestasi akademik

\section{DAFTAR PUSTAKA}

Anggresta, Vella. “Analisis Faktor-Faktor yang Mempengaruhi Prestasi Belajar Mahasiswa Fakultas Ekonomi Universitas Negeri Padang”. ECONOMICA vol 4, no. 1 (2016): h. 28. ISSN : 2302 - 1950, E-ISSN : $2460-190 \mathrm{X}$

Harun, Irma, M. Daud dan Asniar Khumas. "Manajemen Waktu dan Stres Akademik pada Mahasiswa Perguruan Tinggi di Makassar”. h. 2.

Mustaqim. Psikologi Pendidikan. Yogyakarta : Pustaka Pelajar, 2001.
You, Jiwon, Myunghee Kang dan Phoebe Pahng. "Moderating Effects of Academic Emotions between Perceived Academic Control and self-Regulated Learning in Online Courses”. E-Learn 37, no. 2 (2013): h. 2182.

Gudono, "Analisis Data Multivariat”. Yogyakarta : BPFE Yogyakarta, 2015.

Gudono, “Analisis Data Multivariat”. Yogyakarta : BPFE Yogyakarta, 2015.

Akter, Sahriar, dkk, “An Evaluation of PLS Based Complex Models: The Roles of Power Analysis, Predictive Relevance and GoF Index" Proceedings of the $17^{\text {th }}$ Americas Conference on Information system (AMCIS2011), (2011): h. 5.

Eryanto, Henry dan Darma Rika S. "Pengaruh Modal Budaya, Tingkat Pendidikan Orang Tua dan Tingkat Pendapatan Orang Tua terhadap Prestasi Akademik pada Mahasiswa Fakultas Ekonomi Universitas Negeri Jakarta”. Jurnal Pendidikan Ekonomi dan Bisnis 1, no. 1 (2013): h. 42 ISSN : 2302 - 2663 